\title{
Cinsiyet Eşitsizliği, Kadına Yönelik Şiddet ve Sağlık Çalışanlarının Yaklaşımı
}

\author{
Gender Inequality, Violence Against Women and the Approach of Health Care Workers
}

\author{
Selma DAĞCI ${ }^{1}$, Besey ÖREN ${ }^{2}$ \\ 1. İstanbul İl Săğlk Müdürlüğü Kamu Hastaneleri Hizmetleri II. Bölge Başkanlığl, İstanbul, Türkiye. \\ 2. Sağllk Bilimleri Üniversitesi Sağllk Bilimleri Fakültesi, İsanbul, Türkiye
}

Bu çalışma I. Uluslararası II. Ulusal İstanbul Ebelik Günleri, 26-28 Nisan 2018, İstanbul'da poster bildiri olarak sunulmuştur.

\section{$\ddot{O Z E T}$}

Bu derlemede cinsiyet eşitsizliği, Türkiye ve dünyada kadına yönelik şiddetin görünümü, şiddetin nedenleri ve çözüm önerilerinin sunulması amaçlanmıştır. Şiddet tanımlanması ve girişimde bulunulması zor bir durum olmakla birlikte, şiddet sonrası mağdura yönelik koruma, tedavi ve iyileştirme hizmetlerin daha etkili biçimde sunulması ve gerektiği kadar sürekliğinin sağlanması çok büyük önem taşımaktadır. Toplumsal cinsiyet; toplumun kadın ve erkeklere verdiği roller, görevler ve sorumluluklardır. Kadına yönelik şiddet; cinsiyete dayalı olarak gerçekleşen ve kadinlarda fiziksel, cinsel, psikolojik herhangi bir zarar ve üzüntü sonucunu doğuran veya bu sonucu doğurmaya yönelik özel veya kamu yaşaminda gerçekleşebilen her türlü davranıs, tehdit, baskl veya özgürlüğün keyfi olarak engellenmesidir. Kadına yönelik şiddet prekonsepsiyonel öncesi dönemden başlamakta, doğumu takiben de kız bebeklerin öldürülmesi, yetişkinlik ve yaşlılık döneminde de daha çok cinsel istismara uğrama ve dayak olarak kendini sürdürmektedir. Dünya Sağlık Örgütü'nün 2005 yılında 11 ülkede 24.000 kadın üzerinde yaptı̆̆ çalışmada, kadınların; \%13-61'inin fiziksel, \%6-59'unun cinsel, \%15-71'inin hem fiziksel hem de cinsel, $\% 20-75$ 'inin ise duygusal şiddete maruz kaldığ bildirilmektedir. Kadına yönelik şiddeti önlemek ve azaltmak amacıyla birey, aile, toplum ve sağlık çalışanları olarak her grubun üzerine düşen bazı sorumluluklar vardır. Bu bağlamda; hükümet tarafindan yasal düzenlemeler yapılarak; çocuklarl, mağdurları, cinsel tacizden koruyacak yasal uygulamalar desteklenmeli ve güçlendirilmelidir. Sağlık çalışanlarının çalışma ortamlarında hastaları ile yakın ilişki kurmaları, şiddetin saptanması ve girişimi açısından anahtar rol oynamaktadır. Sonuç olarak, sağlık çalı̧̧anları şiddet belirti, bulgu ve girişimleri konusunda eğitilmelidirler.

Anahtar Kelimeler: şiddet, cinsiyet eşitsizliği, sağlık çalışanları, kadın, aile

\section{ABSTRACT}

In this review, gender disparity, the appearance of violence against women in Turkey and the world, the reasons of violence and solution proposals were aimed at presenting. Although it is difficult to define and attempt violence, it is very important to provide protection, treatment and improvement services for post-violence victims more effectively and to ensure continuity as necessary. Social gender is the roles, Duties and responsibilities that society assigns to both men and women.

\section{Iletişim}

Sorumlu Yazar: Selma DAĞCl

Adres: İstanbul II Sağlık Müdürlüğü Kamu Hastaneleri Hizmetleri II. Bölge Başkanlığı, İstanbul, Türkiye

Tel: +90 (212) 6383000

E-Posta: selma.dagci@gmail.com

Makale Geliş: 09.08.2018

Makale Kabul: 09.02.2019

DOI: http://dx.doi.org/10.16948/zktipb.452219
Violence against women; on the basis of gender, and women actual physical, sexual, psychological harm and sadness caused to any private or public behaviour that occur in real life for looking this or that eventuality, threats, coercion or the arbitrary prevention of Liberty. Violence against women begins before the pre-parliamentary period, and after birth, the killing of girls continues as being subjected to sexual abuse and beating. According to the World Health Organization's study on 24.000 women in 11 countries, 13-61\% of women are exposed to physical violence, 6-59\% to sexual violence, $15-71 \%$ to physical and sexual violence, and 20-75\% to emotional violence. In order to prevent and reduce violence against women, there are some responsibilities that fall on each group as individuals, family, community and health workers. In this context, legal arrangements must be made by the government to support and strengthen legal practices to protect children, victims and sexual harassment. Health workers ' close relationships with their patients in working environments play a key role in determining and attempting violence. In this context, health workers should be trained on their symptoms, findings and initiatives.

Keywords: violence, gender inequality, health workers, women, family

\section{GíRIŞ}

Toplumsal cinsiyet; toplumun kadın ve erkeklere verdiği roller, görevler, sorumluluklar ile kişinin cinsiyet temelli olarak ayrımcılığa uğramaması toplumsal yaşamın her alanında eşit olarak yer almasıdır. Toplumsal cinsiyette eşitlik (gender equality): Firsatları kullanma, kaynakların ayrılması ve kullanımında, hizmetleri elde etmede bireyin cinsiyeti nedeniyle ayrımcılık yapılmamasıdır. Biyolojik cinsiyet ise kişinin kadın ya da erkek olarak gösterdiği genetik, fizyolojik ve biyolojik özelliklerdir. TUiK 2013 verilerine göre ülkelerarası toplumsal cinsiyet sıralamasında İzlanda, Finlandiya ve Norveç ilk üç sırada bulunmaktadır. Türkiye küresel cinsiyet uçurumu raporu (2014)'na göre toplumsal cinsiyet eşitliğinde 142 ülke arasında 125. sıradadır. 81 İl İçin Toplumsal Cinsiyet Eşitliği Karnesi (2016)'ne göre İstanbul, Bursa ve Eskişehir en eșitlikçi iller arasında iken; Yozgat, Muş ve Bitlis en eşitsiz iller arasında bulunmaktadır (1). Türkiye'de Toplumsal Cinsiyet ve Kadın Algısı Araștırması (2015)'na göre çalıșmaya katılanların \%71.2'si kadın erkek eșitliği olmadığını savunmuş ve bu görüşü savunanların \%80'nini kadın bireyler oluşturmaktadır. Şiddet, güçlünün güçsüze iradesini kabul ettirme biçimidir ve kaynağı eşitsiz güç ilişsileridir. Kadına yönelik şiddet tiplerini; duygusal, sözlü, ekonomik, cinsel ve fiziksel 
şiddet oluşturmaktadır. Kadına yönelik şiddet, en acımasız yüzünü cinsel şiddet olarak göstermektedir. Şiddetin en yaygın görülen biçimi; erkeğin kadına ve çocuğa karşı uyguladığı aile içi şiddettir. WHO 2002 raporuna göre; şiddetin en fazla, aile ortamında ve kadına yönelik olduğu vurgulanmaktadır.

$\mathrm{Bu}$ derlemenin amacı, son yıllarda ülkemizde artan şiddet vakaları nedeni ile konunun önemine bir kez daha dikkat çekmek amacı ile literatür ışığında cinsiyet eşitsizliği, kadına yönelik şiddetin boyutları ve sağlık çalışanlarının şiddete yaklaşımı tartışmaktır.

\section{Şiddet}

Fiziksel güç veya iktidarın kasıtll bir tehdit veya gerçeklik biçiminde bir başkasına uygulanmas1 sonucunda maruz kalan kişide yaralanma, ölüm ve psikolojik zarara yol açması ya da açma olasılığ bulunmasina şiddet denir. Şiddet, güçlünün güçsüze iradesini kabul ettirme biçimidir. Şiddetin kaynağ 1 eşitsiz güç ilişkileridir (2). Şiddetin; saldırgan şiddet, kadına yönelik şiddet, aile içi şiddet, çocuğa yönelik şiddet, intihar ve yaşlilara yönelik şiddet gibi türleri bulunmaktadır (3).

Kadına yönelik şiddet; cinsiyete dayalı olarak gerçekleşen ve kadınlarda fiziksel, cinsel, psikolojik herhangi bir zarar ve üzüntü sonucunu doğuran veya bu sonucu doğurmaya yönelik özel veya kamu yaşamında gerçekleșebilen her türlü davranış, tehdit, bask1 veya özgürlüğün keyfi olarak engellenmesidir (4).

Kadına yönelik şiddetin tarihsel gelişimi insanlık tarihi ile paraleldir. Kadınların fiziksel şiddet yaşama kökeni 3000 yıl öncesine dayanmaktadır. Literatürde erkek mumyalarda kafatası kırı̆g $1 \% 9$ 20 iken; kadın mumyalarda \%30-50 olduğu bildirilmektedir. Eski Roma yazıtlarında erkeklerin kendilerinden izinsiz oyunlara katıldıkları, zina yaptıkları için eşlerini cezalandırma, boşama ve öldürme haklarına sahip olduğu yazılıdır (5). Orta çağda erkeğin kadına karşı zor kullanmasında sınırın olmadığı bildirilmektedir. Kadına yönelik şiddete ilişkin yasal ve tıbbi çalışmalar 1800'lü yıllara dayanmaktadır. Kadına yönelik şiddeti suç sayan ilk yasa Maryland'de 1883'de yapılmıştır (6).

Kadına yönelik şiddet tiplerini; duygusal, sözlü, ekonomik, cinsel ve fiziksel şiddet oluşturmaktadır ve en acımasız yüzünü cinsel şiddet olarak göstermektedir. Şiddetin en yaygın görülen biçimi; erkeğin kadına ve erkeğin çocuğa karşı uyguladığ 1 aile içi şiddettir (7). WHO 2002 raporuna göre; şiddetin en fazla, aile ortamında ve kadına yönelik olduğu vurgulanmaktadır.

Kadınlara cinsiyet temelli olarak, fiziksel güç kullanılarak, korkutularak, yıldırılarak ve kız çocuklarına cinsiyetleri nedeniyle yönlendirilen zarar verici çok çeşitli davranışlar şiddet biçimleri olarak sıralanmaktadır (8). Kadına yönelik şiddet prekonsepsiyonel öncesi dönemden başlamakta, doğumu takiben de kız bebeklerin öldürülmesi, cinsel istismara uğrama ve dayak olarak kendini sürdürmektedir. Kadınlar yetişkinlik döneminde de çeyiz, başlık paras1, namus cinayeti, flörtte şiddet, evlilikte hırpalanma, dayak, tecavüz, ekonomik ve psikolojik baskı, genital mutilasyon (kadın sünneti), işyerinde cinsel ve psikolojik şiddet, kadın ticareti ve fahişeli- ğe zorlanma, yaşl11ık döneminde ise fiziksel, cinsel, psikolojik saldırıya uğrama ve cinayete kurban gitme gibi çeşitli şiddet türlerine maruz kalmaktadırlar (9). Aile, toplum, hukuk, ekonomik, gelenekler, siyaset ve eğitim kadına yönelik şiddeti üreten dinamikleri oluşturmaktadır.

\section{Dünya'da Kadına Yönelik Şiddetin Boyutları}

Dünya Sağlık Örgütü'nün 11 ülkede 24.000 kadın üzerinde yaptı̆̆ 1 çalışmada, kadınların; \%1361'inin fiziksel, \%6-59'unun cinsel, \%15-71'inin hem fiziksel hem de cinsel, \%20-75'inin ise duygusal şiddete maruz kaldığ 1 bildirilmektedir (10). Kuzey Hindistan'da yaşayan kadınların \%17'sinin fiziksel, \%22'sinin cinsel saldırıya, Doğu Londra'da kadınların \%61'inin aile içi şiddete, \%87'sinin cinsel saldırıya maruz kaldığı bildirilmektedir (11, 12). Nikaragua'da yaşayan kadınların \%52'sinin yaşamlarının bir bölümünde şiddete maruz kaldığg 1 saptanmıştır (13). Japonya' da kadınların \%67'sinin fiziksel şiddeti deneyimledikleri, Danimarka'daki kadınların \%52'sinin, Finlandiya'dakilerin \%47'sinin, İsveç'tekilerin \%46'sının yakın ilişkilerde fiziksel şiddete maruz kaldığ 1 bildirilmektedir (14, 15). Washington'da yapılan araştırmada, kadınların $\% 27$ 'sinin eşleri tarafından fiziksel şiddet gördükleri ve bu kadınların \%24'ünün şiddet sonucunda yaralandıkları; Yunanlı kadınların \%83'ünün fiziksel ve psikolojik şiddete maruz kaldıkları saptanmıştır (11, 12). Dünya Sağlık Örgütü'nün 2013 raporuna göre de dünyadaki kadınların $\% 35$ 'i şiddete maruz kalmakta olup; Güneydoğu Asya'da \%37.7, Afrika'da $\% 36.3$, Amerika'da \%29.8 ve Avrupa' da \%25.4 oranında kadınların eşleri tarafından şiddet gördükleri saptanmıştır (16). Rugira'nın (2015) Tanzanya'da 98 katılımc1 üzerinde yapmış olduğu araştırmada kadınların \%62 oranında sözel şiddete (hakaret içeren), $\% 57$ oranında fiziksel şiddete ve $\% 53$ oranında duygusal şiddete maruz kaldığ tespit edilmiştir (17). Mosleh ve arkadaşları cinsel tacizi "sosyal kanser" ve utanç verici davranış olarak tanımlamaktadırlar (18). Avrupa Birliği Temel Haklar üzerine 23 Avrupa Birliği Üyesi ülkenin katılmış olduğu araștırmada ise kadınların 15 yaşından itibaren fiziksel ya da cinsel şiddete maruz kalma oran $1 \% 33$ olarak bildirilmektedir. Gracia ve ark.'nın (2015) çalışmasında cinsel istismar olarak tecavüze uğrayan kadın oranı $\% 5$ olarak saptanmıştır (19).

AB ülkelerinde FRA (2014) raporuna göre 1874 yaş arası kadınların \%7'si fiziksel, \%2'si cinsel şiddete; 15 yaşından itibaren ise her 20 kadından biri (\%5) tecavüze ve \%18'i de ssrarlı takibe maruz kalmaktadır. Öztürk ve arkadaşlarının (2016) çalışmasına göre Danimarka (\%52), Hollanda (\%45) ve Fransa (\%44) kadına şiddet uygulayan ülkelerin başında yer almakta iken Polonya (\%13), Avusturya (\%20) ve Slovenya $(\% 22)$ son siralarda yer almaktadır. Kadınların aile içi şiddete en fazla uğradığı ülkeler listesinde; Etiyopya, Zambia, Tanzanya, Solomon Adaları, Kolombiya, Peru, Bangladeş, Samoa adalar1 ve Türkiye gibi gelişmekte olan ülkeler bulunmaktadir $(20,21)$.

ABD'deki kadınların yaşam boyu şiddete maruz kalma siklığ1 \%25-54 olarak bulunmuştur. Kanada'da 2001 yılında polise intikal eden şiddet 
suçlarının \%25'i kadına yönelik şiddeti içermektedir; bunun da 2/3'ünün eş veya önceki eş tarafindan uygulandığı saptanmıştır. Kenya'da yapılan bir araştırmada kadınların \%42'si eşleri tarafından düzenli olarak darp edildiklerini ifade etmişlerdir (22).

\section{Türkiye'de Kadına Yönelik Şiddet}

Dünyada olduğu gibi Türkiye'de de şiddet kadını etkileyen faktörlerin başında gelmektedir. Erkeklerin kadına şiddet uygulayabilmesini gerekçe gösteren pek çok faktör sayılabilir. Aile içinde şiddet gören kadın bunu ister ve hak eder inanışına paralel olarak, kadınların \%39'u yemeği yakma, kocaya karş11ık verme, parayı lüzumsuz yere harcama, çocuk bakımını ihmal etme, cinsel ilişkide bulunmay1 reddetme gibi nedenlerin herhangi birisine bağl1 olarak eşlerinin kendilerine fiziksel şiddet uygulayabileceğini kabul etmektedir (23). TNSA 2008 verilerine göre de TNSA 2013 verilerine benzer şekilde toplumun \%24.7'sinin kadının yemeği yakması, kocasına karşıllk vermesi, parayı lüzumsuz yere harcaması, çocuklarının bakımın ihmal etmesi, cinsel ilişkiye girmeyi reddetmesi gibi durumlardan en az birinin gerçekleşmesinin, kocanın karısını dövmesi için haklı gerekçe olarak görmektedir. Bu durum şiddet uygulayan erkekleri de kadınlar yetiştirmektedir, bu sorun kadınlardan kaynaklanmaktadır inanışını bize yansıtmaktadır. Fiziksel, duygusal, cinsel ve ekonomik olarak maruz kalınan şiddet, yerleşim yerine ve bölgeden bölgeye farkl1lık gösterebileceği gibi şiddet eğilimi kişilerin yaş, eğitim, çalışma durumu, medeni durum ve refah düzeyi gibi kriterlere bağlı olarak da farklılık göstermektedir. Türkiye'nin doğusu ile batısı arasında farklı eğitim seviyelerinde, farklı şekillerde, farklı oranlarda ve farklı biçimlerde kadına şiddet uygulanmaktadır (24). Kadına yönelik şiddetin Doğu'da \%39.5, Batı'da \%18.3, lise ve üzeri eğitim görmüş kadınlarda \%5.3, ilkokulu bitirmemişlerde $\% 46.9$, refah düzeyi en yüksek olanlarda $\% 7.1$ ve refah düzeyi en düşük olanlarda ise $\% 42.9$ olduğu saptanmıştır (25). Bu sonuçlar, aile içinde kadına yönelik şiddet çoğunlukla düşük gelirli ailelerde yaşanır inanışı ile paralellik göstermektedir.

Erkeklerden fiziksel şiddet gören kadınların tahmini oranının \%25-50 olduğu rapor edilmiştir (26). Diyarbakır Kadın Sorunlarını Araştırma Uygulama Merkezi (DİKASUM) Raporuna göre; günümüzde ülkemizdeki kadınların $\% 58$ 'i fiziksel, \%63.5'i psikolojik, \%13.5'i cinsel ve \%16.2'si ekonomik şiddete maruz kalmaktadır. Şiddetin \%52.7'si eşi tarafindan, \%14.9'u anne-babası tarafindan, \%5.4'ü ise erkek arkadaşı tarafindan uygulanmaktadır (27). Toplumumuzda kadınlar da şiddeti belirli oranlarda ve şekillerde makul görebilmektedir. TNSA 2013 verilerine göre; fiziksel şiddet yaşanmasına ilişkin en az bir nedeni kabul eden kadınların oranı \%13 olarak belirtilmektedir. Aile Araştırma Kurumu ve Mor Çatı Kadın Sığınağı Vakfi'nın araştırmasına göre toplumun dayağ 1 "terbiye" olarak nitelediği belirtilmektedir. Kadınların çoğu yaşamla$\mathrm{r} 1$ boyunca en az bir kez baba ya da koca şiddetine maruz kalmaktadır.

Türkiye'de Aile İçinde Kadına Yönelik Şiddetin Farklı Görünümleri
Türkiye'de Kadına Yönelik Şiddet Araştırması (2014) verilerine göre; kadınlar yaşamlarının bir döneminde $\% 44$ duygusal, $\% 36$ fiziksel, $\% 30$ ekonomik, \%12 cinsel şiddete ve 27'si 1srarlı takibe maruz kalmışlardır. Erkekler; duygusal istismar yoluyla, çocukları kullanarak, izole ederek, gözdağ1 vererek, inkâr ederek, suçlayarak, küçümseyerek ve erkeklik ayrıcalıklarını kullanarak kadınlara psikolojik şiddet uygulamaktadır. Kadınlar istemediği yerde, zamanda ve biçimde cinsel ilişkiye, çocuk doğurmaya/doğurmamaya ve fuhuşa zorlanarak ayrıca cinsel organlarına zarar verilerek ve cinsel yolla hastalık bulaştırılmasına bağlı olarak cinsel şiddete maruz kalmaktadır $(8,28)$. Ayrica para harcamasının kısıtlanması, çalışmasına izin verilmemesi, zorla çalıştırılması, ekonomik konulardaki kararların erkek tarafından tek başına alınması, parasının elinden alınması, iş yerinde olay yaratmak suretiyle kadının işten atılmasına neden olunması ve kadının iş bulmasını kolaylaştırıcı becerileri geliştirecek etkinliklerin engellenmesi sonucu kadınlar ekonomik şiddete uğramaktadır. Erkekler kadınları itip kakmak, tartaklamak, tokatlamak, tekmelemek, kesici ve vurucu aletlerle bedene zarar vermek, sağl1ksız koşullarda yaşamaya mecbur bırakmak ve sağlık hizmetlerinden yararlanmasina engel olmak suretiyle bedensel zarara uğratarak fiziksel şiddet uygulamaktadır (20). Aile Yapısı Araştırması (2016) sonuçlarına göre; eşler arasında anlaşmazlık olduğunda erkeklerin \%75.3'ünün, kadınların ise \%66.2'sinin eşlerine seslerini yükselterek/bağırarak tepki verdiği ve erkeklerin \%55.1'inin, kadınlarm ise \%64.2'sinin eşleri ile anlaşmazlık durumunda sessiz kaldıkları saptanmıştır. Eş ile anlaşmazlık durumunda erkeklerin \%3.6'sının, kadınların ise \%2.4'ünün eşlerine fiziksel şiddet uyguladığ 1 bildirilmektedir. Ülkemizde Güneydoğu Anadolu Bölgesi'nin (Gaziantep, Ad1yaman, Kilis, Şanlıurfa, Diyarbakır, Mardin, Batman, Şırnak, Siirt) eşlere fiziksel şiddet uygulama oranı en yüksek bölge olduğu ve bu bölgede erkeklerin \%8.6'sının, kadınların \%7.5'i eşlerine fiziksel şiddet uyguladığı saptanmıştır. Erkeklerde fiziksel şiddet uygulama oranının en düşük olduğu bölge \%1.7 ile Ege (İzmir, Aydın, Denizli, Muğla, Manisa, Afyonkarahisar, Kütahya, Uşak) Bölge'si olurken, kadınlarda bu oran \%0.7 ile Doğu Marmara (Bursa, Eskişehir, Bilecik, Kocaeli, Sakarya, Düzce, Bolu, Yalova) Bölgesi' dir. Yapılan çalışmalarda kadınların daha çok fiziksel şiddete maruz kaldığı saptanmıştır $(2,21)$.

Asit atma, asit saldırısı, kezzap saldırısı (vitriolage); asit veya benzeri aşındırıcı bir maddenin çirkinleştirmek, işkence ya da öldürme amacı ile yüze veya gövdeye atma eylemi kadına yönelik şiddet türlerindendir. Bangladeş, Hindistan, Nepal, Kamboçya, Vietnam, Laos, Çin, Kenya, Güney Afrika, Uganda, Pakistan, Afganistan, Kolombiya ve Etiyopya, Güney Amerika, Orta ve Kuzey Afrika, Ortadoğu ve Orta Asya'da ki ülkelerde; okumak istediği, evlenmeyi reddettiği, giyim, başörtüsü, çeyiz, mülkiyet anlaşmazlıkları nedeni ile veya yolda yalnız yürüdüğü için yüzüne asit atılan kadınların olduğu bildirilmektedir (29).

Sözlü şiddet, şiddet tehdidi, herhangi bir eşyayı firlatma, bir eşyayı kadına atma, tokatlama, yumruk 
atma, tekmeleme, vurma, herhangi bir kesici ya da patlayıcı silahla tehdit etme veya o aletle yaralama, cinsel tacizde bulunma ve tecavüz kelimeleri hirpalanmış eş sendromunu tanımlamak için kullanılmaktadir (30).

KSGM (2009) verilerine göre; Türkiye' de her beş kadından ikisi fiziksel şiddet görmekte, her dört kadından biri fiziksel şiddet nedeniyle yaralanmakta, her 10 gebe kadından biri fiziksel şiddete maruz kalmakta, her iki kadından biri duygusal ve her dört kadından biri ekonomik şiddet yaşamaktadır. Aile içinde kadına yönelik şiddet zamanla kendiliğinden sona erer anlayışına paralel olarak yaşadığ ti kimseye anlatamayan kadınların oran1 \%48.5'tir (26). Öztürk vd. (2016)'na göre Türkiye'de sırasılyla Orta (\%43), Batı (\%42) Anadolu ve Batı Karadeniz (\%42) bölgesi kadına şiddetin en fazla olduğu bölgeler olarak sıralanmıştır (20). 2014 yılı jandarma verilerine göre, kadına yönelik şiddettin en fazla olduğu iller Antalya, Muğla ve İzmir olarak belirlenmiştir. Türkiye'de Kadına Yönelik Şiddet Araştırması (2014)'na göre, eğitimi/okuryazarlığ1 olmayan kadınların \%43'ü, ilkokul mezunlarının \%42'si ve üniversite mezunlarının \%21'i fiziksel ve/ya cinsel şiddete maruz kalmaktadır (28). Lise ve üzeri eğitim düzeyindeki kadınların \%27'si, refah düzeyi yüksek olan kadınların da \%29'u şiddete maruz kalmaktadır (20). Türkiye’de Kadına Yönelik Şiddet Araştırması (2014) verilerine göre; şiddet gören kadınların \%89'u herhangi bir kuruma başvurmaz iken, resmi kuruluşa başvuranların ise en fazla (\%7) polise başvurduğu belirlenmiştir. Polise başvuruların \%41'i başka kurum/kuruluşa yönlendirme, \%29'u eşten uzaklaştırma, \%23'ü tedbir kararı ile sonuçlandığı ve başvuruların \%13'üne ise herhangi bir şey yapılmadığı saptanmıştır (28).

\section{Sağlık Personelinin Şiddete Yönelik Yaklaşımı}

Kadına yönelik şiddetin tanılanmasında, önlenmesinde ve tedavisinde sağl1k personelinin önemli rolü vardır. Görünümde fiziksel nedeni olmayan kronik yorgunluklar, verilen açıklamaya uymayan yaralanmalar, aşırı bir nezaket gösteren yine aynı şekilde kontrolü aşırı şekilde elinde bulunduran ya da kadının yanında ayrılmayan bir eş gibi psikolojik belirtiler şiddete maruz kalan kadını bize tanımlayabilir (31). Aynı şekilde hamilelik sırasında fiziksel yaralanma, doğum öncesi bakıma olması gerekenden geç başvurma, intihar girişimi/düşüncesi, dayak sonucu yaralanmalar için tedaviye geç başvuru, idrar yolu enfeksiyonu, kronik irritabl bağırsak sendromu, kronik pelvik ağrı vb. şikayetleri de şiddete maruziyetin belirtileri olabilmektedir (32). Sağlik personeli yukarıda sayılan belirtileri dikkate alarak şiddete uğrayan bireyi saptayabilmelidir.

Aile içi şiddete maruz kalan kadınlarla yapılan çalışmalarda, kadınların çoğunluğunun sağlık kuruluşlarına başvurduklarında kendilerine aile içi şiddete maruz kalıp kalmadıklarının sorulmasını ve durumlarının ortaya çıkarılarak yardım edilmesini istedikleri saptanmıştır (33). McCloskey ve ark.'nın çeşitli sağlık kuruluşlarına farklı şikâyetlerle başvuran 2465 kadınla yaptıkları çalışmada sağlık personeli tarafından aile içi şiddete maruz kalıp kalmadığ 1 sorulan kadınların, sorulmayan kadınlara göre \%36 oranında daha fazla saptandıkları bulunmuştur (34).

Sağlık çalışanları şiddete maruz kalan bireylere, empati, destek, tıbbi tedavi, psikolojik danışmanlık desteğinin yanında, güvenlik planı, takip, bakımı planı ve sürecin takibi ile ilgili destek sağlamalıdır. Aynı zamanda yasal süreç için danışmanlık ve rehberlik yapabilmelidir (35).

Ancak sağlık çalışanları, şiddet olayına ve şiddete uğrayan kadınlara ilgisiz kalabilir, mahrumiyeti (gizliliği) ihlal edebilir, yaşanan istismarın boyutlarını önemsiz görebilir, tavsiye edileni yapmıyorsa, şiddete uğrayan kişiyi suçlar ve yargilayabilirler. Ayrıca sağlık çalışanları şiddet mağdurunun güvenliğe olan ihtiyacını göz ard1 edebilirler (32). Aynı zamanda; şiddete maruz kalan kadınlar, tekrar şiddete maruz kalacağı, utanma ve rezil olma, istismarı hak ettiği düşüncesi ile ayrıca içinde bulunduğu durumu anlayamama, eşini /yakınlarını koruma ve sağlık ça1ışanlarının bilgisi olmadığını ve yardımcı olamayacağı düşüncesi ile yardım veya destek almayı reddedebilmektedirler (36).

Kadına yönelik şiddeti önlemek ve azaltmak amacıyla birey, aile, toplum ve sağlık çalışanları olarak her grubun üzerine düşen bazı sorumluluklar vardır. Bu bağlamda; hükümet tarafından yasal düzenlemeler yapılarak; çocukları, mağdurları, cinsel tacizden koruyacak yasal uygulamalar desteklenmeli ve güçlendirilmelidir. Kadın-erkek eşitliğine önem verilmeli ve kadınlara yönelik şiddete karşı koyma programlarının yaygınlaştırılması sağlanmalıdır (33, 35). Cinsel istismar cinsellik değil, saldırganlıktır bilgisi yaygınlaştırılmalı ve bu bağlamda risk gruplarına yönelik taramalar yapılmalıdır. Sevgili/nişanlı iken başlayan fiziksel ve cinsel zorlayıcı davranışlara tolerans gösterilmemesi konusunda bireyler uyarılmalı ve cinsel taciz/saldırıya uğrayan kişilerin kriz sonrası ve uzun dönemde başvurabileceği ulaşılır merkezlerin kurulması sağlanmalıdır (32). Ergenlerde genç kızların bedenini koruma ve istenmeyen cinselliklere karşı okul ve kamu iletişim araçları ile eğitim yapılmalı ve yaygınlaştırılmalıdır. Cinsiyetçi bakış açısı ve toplumsal rolleri nedeniyle güçsüz konumda olan kadinlara şiddet ve HIV konusunda korunma ve tedavisi ile ilgili program-stratejiler geliştirilmelidir. Cinsel suç mağdurları ve saldırganlara yönelik tedavi programlarının oluşturulması, sistemli olarak düzenlenmesi ve sayısının artırılması sağlanmalidir (33).

\section{Sağlık Kurumlarının Şiddete Müdahale Kapasi- tesini Geliştirmenin Yolları}

Çalışanların şiddete karşı eğitilmesi, bekleme salonlarına posterler asılması, broşürler bırakılması ve şiddet görenle yalnız iletişim için ortam hazırlanması gibi düzenlemelerle kurumların duyarlı hale getirilmesi sağlanmalıdır (33). Şiddet maruz kalan kadınlara yönelik; hasta anamnez formuna şiddeti sorgulayan sorular eklenmeli, nasıl müdahale edileceğiyle ilgili protokoller geliştirilmeli, disiplinler arası işbirliği sağlanmalı ve uygun yerlere sevkleri gerçekleştirilmelidir. Ayrıca, kadına destek verebilecek yerel kadın sivil toplum kuruluşları da dahil olmak üzere savcılık, polis ve sığınma evleri gibi ilgili tüm kamu ya da tüzel kişi kurumlarla ilişkilerin arttırılması sağlanmalıdır (24). 


\section{SONUÇ}

Kadına yönelik şiddet tüm yaş gruplarında artan bir sorun haline gelmekle birlikte sadece Türkiye'nin değil aynı zamanda dünyanın sorunudur. Şiddete uğrayan kadınlar, utanma, suçluluk hissetme, güvenmeme, ümitsizlik, sorunun çözülemeyeceği inancı gibi nedenler ile sorunu paylaşmamakta ve yardım almaktan kaçınabilmektedirler. Şiddet ile mücadele etmek için multidisipliner mücadele gerekmektedir. Bu sebeple sağlık çalışanlarının, polisin ve adli personelin kadına yönelik şiddeti düşündüren durumları iyi bilmeleri ve şiddete maruz kalan bireylere yaklaşımı büyük önem taşımaktadır. Ayrıca sağlık çalıșanları ve kolluk kuvvetlerinin kadın erkek firsat eşitliği ve şiddeti önleme konularında eğitilmeleri gerekmektedir. Bu doğrultuda kadına yönelik şiddetin durdurulması, önlenmesi ve saptanmasında; sağlık çalışanlarının kayıt tutma, kişileri saptama, veri toplama gibi önemli sorumlulukları vardır. Ayrıca; şiddetin önlenmesinde sağlık çalışanlarının desteklenmesi, sağduyusunun arttırılmas1 ve yasal olarak güçlendirilmeleri önerilmektedir.

\section{KAYNAKLAR}

1. Sener Ü, Demirdirek Ü. 81 İl İçin Toplumsal Cinsiyet Essitliği Karnesi, Tepav 2016; 1-19.

2. Bal M. Toplumsal Cinsiyet Eşitsizliğine Genel Bakış. KASHED 2014; 1(1): 15-28.

3. Eliuz U. Cinsel Kimlik Paniği: Kadın Olmak. Panic Of Sexual Idenity: Being A Woman. Turkish Studies 2011; 6(3): 221-232.

4. Kaplan S, Akalın A, Pınar G, Yılmazer T. Hemşirelik öğrencilerinin kadına yönelik aile içi şiddet ve aile içi şiddette mesleki rollerine ilişkin tutumları. Yıldırım Beyazıt Üniversitesi Sağlık Bilimleri Fakültesi Hemşirelik E-Dergisi 2014; 2(1): 26-35.

5. Vatandaș C. Aile ve Şiddet: Türkiye'de Eșler Arası Şiddet.1.Baskı, Ankara, Uyum Ajans 2003; 173-176.

6. Dişsiz M. Hotun-Şahin N. Evrensel bir kadın sağlı̆̆ sorunu: kadına yönelik şiddet. Maltepe Üniversitesi Hemşirelik Bilim ve Sanatı Dergisi 2008; 1(1): 50-58.

7. Güler N, Tel H, Özkan-Tuncay F. Kadının aile içinde yaşanan şiddete bakışı. C. Ü. Tıp Fakültesi Dergisi 2005; 27 (2): 51-56.

8. Yörük S. Kadına yönelik şiddet: Antalya örneği. Yayınlanmamış Yüksek Lisans Tezi, Akdeniz Üniversitesi Sosyal Bilimler Enstitüsü, Antalya 2010

9. Üner S. Toplumsal Cinsiyet Eşitliği. T.C. Başbakanlık Kadının Statüsü Genel Müdürlüğü, Ankara Dumat Ofset 2008; 6-20.

10. World Health Organization (2005). Gender in mental health research. Erişim Tarihi: 13.10.2017; Erişim Adresi: Geneva, http://www.who. int/gender/documents/en/mentalhealthlow.pdf,

11. Falb KL, Annan J, Kpebo D, Cole H, Willie T, Xuan Z, Raj A, Gupta $J$. Differential impacts of an intimate partner violence prevention program based on child marriage status in rural Côte d'Ivoire. Journal of Adolescent Health 2015; 57(5): 553-558.

12. Belhorma S. Two months of marriage were sufficient to turn my life upside down: Early marriage as a form of gender-based violence. Gender \& Development 2016; 24(2): 219-230.

13. Ellsberg M, Pena R, Herrera A. et al. Candies in hell: women's experiences of violence in Nicaragua. Social Science \& Medicine 2000; 51(11): 1595-1609.

14. Weingourt R, Maruyama T, Sawada I, et al. Domestic violence and women's mental health in Japan. International Nursing Review 2001; 48 (2): $102-108$.

15. Duman NB, Büyükgönenç L, Güngör T, Yılmazel G, Topuz Ş, Koçak
DY. Sağlık Çalışanlarının Kadına Yönelik Şiddet Algllayışı ve Etkileyen Faktörler. Jinekoloji-Obstetrik ve Neonatoloji Tip Dergisi 2016; 13(4): 154-159.

16. World Health Organization, Global and Regional Estimates of Violence against Women, For individual country information, see full compilation of data in UN Women, (2012). Violence against Women Prevalence Data: Surveys by Country. Erisim Tarihi: 15.10.2017; Erişim Adresi: http://apps.who.int/iris/bitstream/10665/85239/1/9789241564625_eng.pdf, p2,.

17. Rugira J. Forms, Causes and Effects of Violence Aganist Women in Mbulu Tanzania. General Education Journal, Published by Mount Meru University Research Unit 2015; 4(1): 16-31.

18. Mosleh H, Rehab A, Farzaneh R, Lori SA. Advancing Egyptian Society By Ending Vionelce Against Women, Published by Population Reference Burea 2015; 1-8.

19. Gracia E, Marisol L. Attitudes Towards Violence Against Women in The EU, Publishing house: European Commission 2015; 1-145, ISBN 978-92-79-53404-1.

20. Öztürk Ö, Öztürk Ö, Tapan B. Kadına yönelik şiddetin kadın ve toplum sağlığ üzerine etkileri. Sağlık Akademisyenleri Derneği 2016; 3(4): 139-144.

21. Uçar A. İstatistikî Verilerle Ulusal Basında Kadına Karşı Şiddet. Inönü Üniversitesi Hukuk Fakültesi Dergisi 2016; 7(2): 315-364.

22. Yetim D, Şahin ME. Aile Hekimliğinde Kadına Yönelik Şiddete Yaklaşım. Aile Hekimliği Dergisi 2008; 2(2): 48-53.

23. WHO, (2002). Intimate partner violence, , Erişim Tarihi: 13.10.2017; Erişim Adresi:http://www.who.int/violence_injury_prevention/violence/world report/factsheets/en/ipvfacts.pdf.

24. Ergönen-Akça T, Özdemir MH, Salaçin S. Kadına Yönelik Aile Iç̧i Siddet Tanısinda Acil Servislerin Rolü: Bir Olgu Sunumu. Turk J Emerg Med 2002; 2(2): 45-49.

25. Türkiye Nüfus ve Sağlık Araştırması (TNSA), (2008). Hacettepe Üniversitesi Nüfus Etütleri Enstitüsü. Ankara, Türkiye. Erișim Tarihi: 26.11.2017; Erișim Adresi: http://www.hips.hacettepe.edu.tr/TNSA2008-AnaRapor.pdf,

26. KSGM, Aile Içi Siddetle Mücadele El Kitabı, T.C. Basbakanlık Kadının Statüsü Genel Müdürlügü̈, Kadınlar Içcin Aile Iç̧i Şiddetle Mücadele El Kitabl, Ankara 2009; 6-8.

27. Imam A. (2012). Bassam; Feminology: Woman Abuse. Erisim Tarihi: 13.10.2017; Erişim Adresi: http://www.freebooks.net/ebook/Feminology-Woman-abuse-2/pdf/view, 1-10

28. Türkiye'de Kadına Yönelik Aile İçi Șiddet Araștırması Özet Rapor, (2014). Erişim Tarihi: 10.10.2017; Erişim Adresi: http://www.hips.hacettepe.edu.tr/KKSA-TRAnaRaporKitap26Mart.pdf

29. Atan ŞÜ. Töre ve Namus Cinayetleri. Turkiye Klinikleri J Obstet Womens Health Dis Nurs-Special Topics 2016; 2(2): 67-73.

30. İsleğen Y. Kadına Yönelik Siddete Jinekolojik Yaklașım. Kadına Yönelik Şiddet ve Hekimlik Sempozyumu: Ankara, 16-17 Kasım 2002. Ankara: Ankara Tabip Odası Yayınları 2003; 71-84.

31. Akın A. Toplumsal Cinsiyet Kadın ve Sağllk. Hacettepe Üniversitesi Yayınlart 2003; 8(11): 20-25.

32. Kayrın N. Fiziksel Siddete Ŭgramıș Kadınlar ve Tiptan Beklentileri: Kadın Hasta Hakları Çerçevesinde Bir Değerlendirme (Tez), Çukurova Üniversitesi, Adana, 2011.

33. Efe S. Acil Servis Hemsirelerinin Kadına Yönelik Aile Icci Siddete Iliş̧kin Rol ve Sorumluluklarl. F. Ü. Sağ. Bil. Tip Dergisi 2012; 26 (1): 49-54.

34. McCloskey LA, Lichter E, Ganz ML, et al. Intimate partner violence and patient screening across medical specialties. Acad Emerg Med $2005 ; 12(8): 712-722$

35. Tanrıverdi G, Şıpkın S. Çanakkale'de Sağlık Ocaklarına Başvuran Kadınların Eğitim Durumunun Şiddet Görme Düzeyine Etkisi. Fırat Tip Dergisi 2008; 13(3): 183-187.

36. Akın A. Kadına Yönelik Aile İçi Şiddetin Kadın Sağlı̆̆ına Etkileri: Kadına Yönelik Aile İçi Siddetle Mücadelede Sağlık Hizmetleri. Ankara: T.C. Başbakanlık Kadının Statüsü Genel Müdürlüğü Yayını 2008; $1-159$. 